\title{
Impact of Catering Incentives on Dividend Payment Decisions: Evidence from Indian Firms
}

\author{
Nishant Labhane*
}

\begin{abstract}
Manuscript type: Research paper

Research aims: The present study examines whether the catering incentives of dividends can influence firms' dividend payment decision for 781 sample firms listed on the National Stock Exchange (NSE) of India during the period of 1995-2015.

Design/Methodology/Approach: This study uses dividend premiums to measure the catering incentives of the dividends. The firms' dividend payment decision is measured by the propensity to pay dividends, and the decision to change dividend payments.

Research findings: The empirical results indicate that the catering incentives of dividends have a significant positive impact on the changes in the propensity to pay dividends. The findings suggest that the higher dividend premiums indicating the investors' higher demand for dividends can induce managers to increase the amount of dividends paid. Firm managers are less likely to cut or omit dividends when the investors' demand for dividends is high as reflected by the higher dividend premiums.

Theoretical contribution/Originality: The catering theory of dividend which is based on investor sentiment is new, and the empirical evidence supporting this theory is limited. This study aims to contribute to existing literature by examining whether the catering incentives of dividends can influence firms' dividend payment decision, in the context of India, during the period of liberalisation.
\end{abstract}

\footnotetext{
* Nishant B. Labhane is an Assistant Professor at the School of Management, National Institute
} of Technology Warangal - 506004, TS, India. Email: nishant.labhane@hotmail.com

https://doi.org/10.22452/ajba.vol12no2.4 
Practitioner/Policy implication: This study has an implication for the management team. The investors in the Indian capital market show a preference for dividend payment. Firm managers could use these catering incentives for deciding dividend payments to investors.

Research limitation/Implications: As the study has not used the primary survey approach to collect data, it could not examine the corporate managers' and the investors' views about the determinants of the dividend policy. New insights could thus be provided by analysing the behaviour of other forms of dividends like bonus shares, stock splits and the share buybacks.

Keywords: Catering Incentives, Dividends, Dividend Policy, Dividend Premium, Propensity to Pay

JEL Classification: G30, G35

\section{Introduction}

Black $(1976$, p. 8) contends, "The harder we look at the dividend picture, the more it seems like a puzzle, with pieces that just do not fit together". This explains why little is understood about why firms pay dividends and why investors value them. Researchers face many great challenges when trying to unravel some answers which could shed some light into the corporate sector's dividend policy due to its sensitive nature. Miller and Modigliani (1961) proposed the irrelevance proposition which suggests that in perfect capital markets with no taxes, zero transaction and agency costs, full availability of information and dividend policies are equivalent. No policy can increase the shareholders' wealth. Over the years, researchers (Jensen \& Meckling, 1976; Bhattacharya, 1979; Litzenberger \& Ramaswamy, 1979; Aharony \& Swary, 1980; Rozeff, 1982; Easterbrook, 1984; DeAngelo, DeAngelo \& Stulz, 2006) have developed alternative theories to explain why firms pay dividends. These theories which opposed the unrealistic assumptions of Miller and Modigliani (1961) in imperfect markets include tax clientele, signalling, agency costs and firm life cycle theories. Thus far, there has been no consensus among researchers on the subject of dividend policy.

Baker and Wurgler (2004a) proposed the catering theory of dividends as a way to explain why firms pay dividends. They explained that firm managers catered rationally to the time-varying investors' demand for dividends by paying dividends to the investors only when these investors put a premium on the dividend-paying stocks, or viceversa. Several proxies were constructed to reflect the dividend premiums 
so as to capture the time-varying investors' demand for dividends. In their study, Baker and Wurgler (2004a) found a positive relationship between the rate of dividend initiation and the dividend premiums. The propensity to pay dividends (Fama \& French, 2001) was also found to be positively related to the dividend premiums. Here, "propensity to pay" was defined as the difference between the actual percentage of dividend payers, and the expected percentage of dividend payers, based on prevailing sample characteristics (Fama \& French, 2001).

Interest in the catering theory of dividends has been growing since the seminal paper of Baker and Wurgler (2004a). Many researchers (see Baker \& Wurgler, 2004b; Denis \& Osobov, 2008; Ferris, Sen, \& Yui, 2006a, 2006b; Ferris, Jayaraman, \& Sabherwal, 2009; Hoberg \& Prabhala, 2008; Tangjitprom, 2013) have examined the influence of the catering incentive of dividends on firms' decision to pay dividends. Most of these studies (Baker \& Wurgler, 2004a, 2004b; Hoberg \& Prabhala, 2008) investigated the impact of catering incentives on dividend payment decisions in developed capital markets like the United States and the United Kingdom (Ferris et al., 2006b). There seems to be scant studies examining the catering effect of dividends in emerging capital markets (Tangjitprom, 2013). Further, the empirical results drawn from previous studies have been mixed, with no definitive conclusion to explain whether the investors' desire for dividends influenced the dividend payment decisions.

Although generally limited, the investigation of firms' dividend payment decisions in an emerging capital market like India have been done before (see Mahapatra \& Sahu, 1993; Bhat \& Pandey, 1994; Baker \& Kapoor, 2015; Labhane \& Mahakud, 2016). However, these studies have not explored the impact of catering incentives on dividend payment decisions specifically. Although Labhane (2017) had examined the influence of catering incentives on the propensity to pay dividends in an Indian context, he did not consider the impact of the catering incentives on the decision to change dividend payout levels. Further to this, studies conducted during the period of 1960-2010 within India had mainly focused on theories related to tax-clientele, agency cost, free cash-flow, the asymmetric information and the signalling theory of dividends. The catering theory of dividend, which is based on investor sentiment, is a new research interest, hence the empirical evidence for supporting this theory is still limited.

This study specifically examines whether the catering incentives of dividends can influence the propensity to pay dividends, and the 
dividend payout levels of listed firms in India during the period of 199495 to 2014-15, hereby considered as India's period of liberalisation. This study contributes to the existing literature by providing more empirical evidence to support the theory of catering incentives of dividends.

The remainder of this paper is organised as follows: Section 2 reviews the empirical literature on the effect of dividend catering on the dividend payment decision, Section 3 describes the data and the period of study, Section 4 specifies the variables used in the study, Section 5 describes the model specification and methodology, Section 6 discusses the empirical results of the study, and the last section concludes the paper.

\section{Literature Review}

This section reviews the empirical literature which looked at the influence of catering incentives of dividends on firms' dividend payment decisions in developed as well as emerging capital markets.

By taking into account the non-financial and non-utilities of US firms during the period of 1962-2000, Baker and Wurgler (2004a) found that firms' decision to initiate or to omit dividends payment was determined first by the prevailing investors' preference for dividends and second by the firm managers who catered rationally to the investors' demand. These managers paid the dividends to the investors when the investors preferred dividend-paying firms, and vice-versa. Following this, Baker and Wurgler (2004b) also examined the impact of the catering incentives of dividends on the propensity to pay dividends. They observed that there was a strong connection between the propensity to pay dividends, and the corresponding variation in the stock market dividend premiums which proxied for the catering incentives of dividends, during 1963-2000. When investors placed a premium on the dividend payers, managers would cater to the investors' demand for dividends by paying the dividends. Hence, the propensity to pay dividends had arisen. However, the propensity to pay dividends decreased when the stock market dividend premiums were negative, and when investors placed a demand for "growth stocks", that is, nondividend paying firms.

After controlling for risks, Hoberg and Prabhala (2008) found that the catering incentives of dividends were no longer significant for explaining the decline in the propensity to pay dividends among 
US firms. Ferris et al. (2006b) then investigated the trend among a number of dividend payers in the United Kingdom (UK). It was found that firms paying dividends had declined from 75.9 per cent to 54.50 per cent between 1988 to 2002. It was also uncovered that the decline in the propensity to pay dividends during the sub-period of 1998-2002 happened once firms were able to control the firm size and profitability. Hoberg and Prabhala (2008) attributed the shift in the catering incentives of dividends to the recent changes happening in the dividend payout policies of the United Kingdom (UK). In another study, Denis and Osobov (2008) examined the empirical determinants of the propensity to pay dividends in six developed financial markets (the United States, Canada, the United Kingdom, Germany, France, and Japan) between 1989 to 2002 . There was little evidence to show that either the propensity to pay dividends or the time-series changes in that propensity could explain the changes in the investors' preference for the dividend-paying stocks.

Using a large sample of firms representing twenty-three different countries, Ferris et al. (2009) analysed the effect of dividend catering on the propensity to pay dividends during 1996 to 2004. They found that dividend catering was more likely to happen in common law countries than in civil law countries, particularly those operating under French or German civil law. Examining the influence of catering incentives of dividends on firms' dividend payment decisions in Thailand, Tangjitprom (2013) noted that the dividend premium acting as proxy for the catering incentives of dividends was mainly positive during 1992 to 2009. This phenomenon implied that investors in Thailand preferred dividends. The findings further suggested that the catering incentives affected the decision of firms in paying dividends. This acted as a control for the Asian financial crisis during 1997-1999. It appeared that the dividend premiums had reduced the likelihood of firms' decision to cut dividend payments from previous years. Overall, Tangjitprom's (2013) study was able to provide evidence in support of the catering theory of dividends.

Investigating the dividend policy of firms listed in Eurozone member countries, Neves (2017) noticed that the catering incentives of dividends had a positive impact on the dividend payout ratios once there was control for the firm-specific determinants of dividends such as size, earnings, tangible fixed assets, leverage and free cash flow. In their study, Baker, Kilincarslan and Arsal (2018) found that corporate 
managers of the Bursa Istanbul (BIST) listed firms perceived that dividend payment decisions influenced firms' value. These managers further expressed a strong support for the bird-in-the-hand idea, which comprised the firms' life-cycle, and the catering theory of dividends. Budiarso, Subroto, Sutrisno and Pontoh (2019) also examined whether firms' life-cycle, and the catering theory of dividends would work in the case of the Indonesian Stock Exchange (ISE) listed firms during 2010-16. They discovered that the dividend premiums were insignificant in all the models. This implied that the catering incentives of dividends did not influence the dividend behaviour, or the policy of the higher or lower dividend-paying firms in Indonesia.

Many studies have investigated the factors which affected the Indian firm's dividend payment decisions. For example, Mahapatra and Sahu (1993) found that cash flows, current earnings and past dividends were the principal factors influencing the dividend policy. However, Bhat and Pandey (1994) used the Lintner (1956) model in their study, and they noted that the firms' current year's profits, expected future profits, past dividends and change in equity, affected the firms' dividend payment decisions. Baker and Kapoor (2015) also examined the factors affecting the dividend policy of India's National Stock Exchange (NSE) listed firms. They noted that the stability of earnings, the level of current and expected future earnings, and the patterns of past dividends, could be some of the most important determinants of dividends. Baker and Kapoor (2015) further used the firms' life cycle, signalling and the catering incentives to explain the paying of dividends by firms.

Analysing the determinants of the dividend policy of Indian listed companies, Labhane and Mahakud (2016) revealed that firms that were larger, more profitable, more mature and highly liquefied have higher dividend payout ratios. In contrast, firms with high investment opportunity, financial leverage, and business risks, have lower dividend payout ratios. This finding supported a number of theories including the pecking order theory, the transaction cost theory, the signalling theory, and the firm's lifecycle theory of the dividend policy. Among some of the studies which can show whether the catering incentives of dividends can influence the firms' dividend payment decisions in the context of India are Labhane (2017), who examined the determinants of dividend payout policy for the Bombay Stock Exchange (BSE) listed firms. He uncovered three distinct trends in the propensity to pay dividends during 1995 to 2013 and he also found that the catering incentives of 
dividends had a significant positive influence on the propensity to pay dividends.

The review of available studies on the influence of the catering incentives of dividends on firms' dividend payment decisions uncovered at least three research gaps. First, most of the previous studies (see Baker \& Wurgler, 2004a; Baker \& Wurgler, 2004b; Hoberg \& Prabhala, 2008) have largely focused on developed capital markets, such as the United States and to some extent the United Kingdom (see Ferris et al., 2006b). Few studies (see Labhane, 2017) have examined this issue in emerging capital markets like India. Second, Baker and Wurgler (2004a) gave a discrete model which takes into consideration only two dividend payment decisions, that is, the decision to initiate or to omit dividends. Their discrete model considered the effect of the catering incentives on the decision to pay or not to pay dividends. It did not consider the impact of the catering incentives on the dividend payout levels. Third, the results obtained from previous studies were not consistent as they were mixed, hence not conclusive. Therefore, it is important to investigate the catering effect of dividends in emerging capital markets like India.

\section{Data and Period of Study}

The data for this empirical study were derived from the PROWESS database, maintained by the Centre for Monitoring Indian Economy (CMIE). It is a leading business and economic database, and research company in India. The period of study used dated from the financial year 1994-95 to 2014-15. The Indian government considers its financial year from 1st April to 31st March midnight. Therefore, the financial year 1994-95 will be referred to as 1995, and accordingly, the financial year 2014-15 will be referred to as 2015. Presently, 1,730 firms are enlisted on the NSE which consists of 179 financial services firms, 28 utilities sector firms, and 35 public sector undertaking firms. This study excludes financial services, and utilities sector companies due to the differences in the accounting practices, and the regulation norms followed. The public sector undertaking companies were also excluded from the sample as their dividend policies are highly influenced by the government's financial considerations and social obligations. Of the remaining 1,488 non-financial services, non-utilities sector and non-public sector companies, the maximum companies required for this study, inclusive of all the explanatory variables without any missing values, amounted to 781 companies. 


\section{Variables}

\subsection{Propensity to Pay Dividends}

To examine the unexplained decrease, and increase in the proportion of dividend-paying firms, this study estimates the propensity to pay dividends $\left(P T P_{t}\right)$ which is defined as the difference between the actual and expected percentage of dividend-paying firms. The actual percentage is the number of dividends-paying firms divided by the total number of firms in the sample for that year. The expected percentage is the percentage of firms that would be expected to be dividend payers, based on prevailing sample characteristics. When the actual proportion of dividend-paying firms are higher than expected, the study considers that the propensity to pay dividends has increased, and vice-versa.

Following Fama and French (2001), the current study estimates the expected percentage of dividend payers by using a logit model which includes the size, profitability, growth opportunities and investment opportunities as the independent variables during the base period of 1995-2003. The base period was chosen in such a way that the study also acquired a similar time span over both the base, and out-of-sample periods. Additionally, the base period represents the post-liberalisation period, and the out-of-sample period represents the period of secondgeneration reform in India. The logit model used is specified as follows:

$$
\begin{aligned}
& \operatorname{Pr}\left(\text { Payers }_{\mathrm{i}}=1\right)= \operatorname{logit}\left\{\alpha_{1}+\beta_{1} \text { SIZE }_{\mathrm{i}}+\beta_{2} \text { PROF }_{\mathrm{i}}+\beta_{3} \mathrm{GRW}_{\mathrm{i}}+\right. \\
&\left.\beta_{4} \mathrm{INVT}_{\mathrm{i}}+\varepsilon_{\mathrm{i}}\right\}
\end{aligned}
$$

where $\mathrm{SIZE}_{\mathrm{i}}$ is firm's size measured as the natural log of market capitalisation, $\mathrm{PROF}_{\mathrm{i}}$ is firm's profitability measured as earnings before interest and taxes, divided by total equity, $\mathrm{GRW}_{\mathrm{i}}$ is firm's growth opportunities measured as annual growth in sales, INVT $\mathrm{IN}_{\mathrm{i}}$ is firm's investment opportunities measured as market value of equity divided by the book value of equity, that is, market-to-book ratio, $\alpha$ is a constant, $\beta s$ are the slope coefficients, and $\varepsilon_{\mathrm{i}}$ is the error term.

Fama and French (2001) advocated that the upward drift in the market-to-book ratio was not due to improved investment opportunities. It was the declining discount rates which played a role in the drift in market-to-book ratio during the study period. In this case, the regression that used size, profitability, growth opportunities and investment opportunities to explain the probability that firms pay dividends had overestimated the decline in the percentage of dividend-paying firms due to changing characteristics. Simultaneously, the regression also 
understated the decline in the percentage of dividend-paying firms due to the propensity to pay dividends. Therefore, to examine the robustness of the various results of the regression analysis, this study excluded market-to-book ratio (MBR) as proxy for investment opportunities, based on equation (1). This follows Fama and French (2001), and Baker and Wurgler (2004b). After excluding the market-to-book ratio (MBR), equation (1) thus becomes equation 2, as below:

$$
\operatorname{Pr}\left(\text { Payers }_{\mathrm{i}}=1\right)=\operatorname{logit}\left\{\alpha_{1}+\beta_{1} \mathrm{SIZE}_{\mathrm{i}}+\beta_{2} \mathrm{PROF}_{\mathrm{i}}+\beta_{3} \mathrm{GRW}_{\mathrm{i}}+\varepsilon_{\mathrm{i}}\right\}
$$

First, equations (1) and (2) were regressed for each year of the baseperiod 1995-2003 so as to generate individual results. Next, the average of the coefficients of each year extracted from the regressions, known as the Fama-MacBeth coefficient, were used to achieve the final logit model. This logit model was finally utilised to estimate the expected percentage of the dividend payers. Thus, this study used two models (1) and (2) to obtain the propensity to pay dividends. The results are shown in Table 1.

Panels A and B in Table 1 demonstrate the logistics estimation results of equations (1) and (2). In this study, the Wald test was used to examine the overall significance of the models. The Wald test follows the $\chi^{2}$ distribution and the statistics were noted to be significant for each year in the base-period 1995-2003, in panels A and B of Table 1. This therefore, rejects the null hypothesis which states that in the regression equation, all the parameters are jointly equal to zero. The expected signs of all the coefficients were found to be consistent with Baker and Wurgler (2004b). The Fama-Macbeth coefficients were also computed from the average of those cross-sectional coefficients, as shown in the bottom lines of Table 1 . These coefficients were used to predict the likelihood of each firm paying a dividend for the entire period of the study. The average of all the firms' predicted probability were computed for each year. This would generate the expected proportion of firms paying dividends in that particular year. Table 2 highlights more results.

Table 2 shows that the expected proportion of the dividendpaying firms was higher than the actual proportion of firms paying dividends during 1995-2002. Hereafter, the expected proportion of the dividend-paying firms decreased continuously, and during 2003-2008, the expected proportion was lower than the actual proportion. During 2009-2015, the expected proportion of firms paying dividends was higher than the actual proportion of firms paying dividends. The actual and the expected percentage of dividend-paying firms was utilised to obtain the propensity to pay dividends $\left(P T P_{t}\right)$, which referred to the 
Table 1: Fama-Macbeth Coefficients Used for Calculation of Propensity to Pay Dividends (Results of Logistic Regressions)

\begin{tabular}{lcccccc}
\hline \multicolumn{7}{l}{ Panel A. Including MBR (market-to-book ratio) } \\
\hline Year & Constant & SIZE & PROF & GRW & INVT & Wald Test \\
\hline 1995 & -1.53 & 0.67 & 3.65 & 1.01 & -0.19 & $104.83^{* * *}$ \\
1996 & -1.61 & 0.83 & 4.54 & 1.62 & -0.34 & $122.99^{* * *}$ \\
1997 & -1.63 & 0.86 & 5.72 & 0.77 & -0.34 & $133.37^{* * *}$ \\
1998 & -1.93 & 0.81 & 6.57 & 0.54 & -0.30 & $146.13^{* * *}$ \\
1999 & -2.46 & 0.78 & 4.25 & 0.63 & -0.16 & $150.82^{* * *}$ \\
2000 & -2.56 & 0.91 & 4.12 & 1.16 & -0.28 & $162.24^{* * *}$ \\
2001 & -2.14 & 0.83 & 2.67 & 1.20 & -0.36 & $151.42^{* * *}$ \\
2002 & -2.43 & 0.71 & 2.61 & 3.30 & -0.17 & $153.10^{* * *}$ \\
2003 & -2.72 & 0.70 & 2.44 & 1.45 & -0.11 & $142.27^{* * *}$ \\
Average & -2.11 & 0.79 & 4.06 & 1.30 & -0.25 & \\
\hline
\end{tabular}

Panel B. Excluding MBR (market-to-book ratio)

\begin{tabular}{lccccc}
\hline Year & Constant & SIZE & PROF & GRW & Wald Test \\
\hline 1995 & -1.44 & 0.57 & 2.99 & 0.84 & $94.14^{* * *}$ \\
1996 & -1.40 & 0.63 & 3.98 & 1.56 & $111.48^{* * *}$ \\
1997 & -1.34 & 0.68 & 4.91 & 0.52 & $119.66^{* * *}$ \\
1998 & -1.61 & 0.63 & 5.67 & 0.41 & $134.69^{* * *}$ \\
1999 & -2.24 & 0.67 & 4.07 & 0.40 & $143.48^{* * *}$ \\
2000 & -2.26 & 0.75 & 3.80 & 0.73 & $151.11^{* * *}$ \\
2001 & -1.88 & 0.65 & 2.46 & 0.98 & $136.9^{* * *}$ \\
2002 & -2.28 & 0.62 & 2.51 & 3.18 & $147.74^{* * *}$ \\
2003 & -2.56 & 0.61 & 2.42 & 1.27 & $138.88^{* * *}$ \\
Average & -1.89 & 0.65 & 3.65 & 1.10 & \\
\hline
\end{tabular}

Notes: SIZE is firm's size measured as the natural log of market capitalisation; PROF is a firm's profitability measured as earnings before interest and taxes divided by total equity; GRW is firm's growth opportunities measured as annual growth in sales; INVT is a firm's investment opportunities measured as market value of equity divided by book value of equity, i.e. market-to-book ratio. ***, **, * indicates significance at 1 per cent, 5 per cent and 10 per cent levels respectively. The logit regression equations are regressed based on models (1) and (2) for every year in the base-period 1995-2003 to obtain individual results in each year. The Fama-Macbeth coefficients are obtained in the second step by averaging the value of coefficients in each year in order to get the final logit model. Then the final logit model is used to estimate the expected proportion of firms paying dividends in each year during 1995-2015. 
Table 2: Actual and Expected Percentage of Payers and the Propensity to Pay Dividends (MBR Included and Excluded)

\begin{tabular}{|c|c|c|c|c|c|c|}
\hline \multirow[t]{2}{*}{ Year } & \multicolumn{3}{|c|}{ MBR Included } & \multicolumn{3}{|c|}{ MBR Excluded } \\
\hline & $\begin{array}{l}\text { Actual } \\
\text { percent }\end{array}$ & $\begin{array}{c}\text { Expected } \\
\text { percent }\end{array}$ & РТP & $\begin{array}{l}\text { Actual } \\
\text { percent }\end{array}$ & $\begin{array}{c}\text { Expected } \\
\text { percent }\end{array}$ & PTP \\
\hline 1995 & 0.80 & 0.85 & -0.06 & 0.80 & 0.82 & -0.03 \\
\hline 1996 & 0.80 & 0.88 & -0.08 & 0.80 & 0.88 & -0.08 \\
\hline 1997 & 0.77 & 0.89 & -0.12 & 0.77 & 0.93 & -0.16 \\
\hline 1998 & 0.71 & 0.87 & -0.16 & 0.71 & 0.94 & -0.24 \\
\hline 1999 & 0.65 & 0.83 & -0.18 & 0.65 & 0.92 & -0.27 \\
\hline 2000 & 0.66 & 0.80 & -0.14 & 0.66 & 0.96 & -0.30 \\
\hline 2001 & 0.63 & 0.75 & -0.12 & 0.63 & 0.80 & -0.16 \\
\hline 2002 & 0.60 & 0.70 & -0.10 & 0.60 & 0.87 & -0.27 \\
\hline 2003 & 0.62 & 0.52 & 0.10 & 0.62 & 0.49 & 0.13 \\
\hline 2004 & 0.67 & 0.50 & 0.17 & 0.67 & 0.43 & 0.23 \\
\hline 2005 & 0.72 & 0.45 & 0.27 & 0.72 & 0.39 & 0.33 \\
\hline 2006 & 0.76 & 0.50 & 0.27 & 0.76 & 0.42 & 0.35 \\
\hline 2007 & 0.77 & 0.61 & 0.16 & 0.77 & 0.54 & 0.22 \\
\hline 2008 & 0.77 & 0.67 & 0.10 & 0.77 & 0.65 & 0.12 \\
\hline 2009 & 0.71 & 0.89 & -0.18 & 0.71 & 0.91 & -0.20 \\
\hline 2010 & 0.76 & 0.95 & -0.19 & 0.76 & 0.95 & -0.19 \\
\hline 2011 & 0.74 & 0.89 & -0.15 & 0.74 & 0.97 & -0.23 \\
\hline 2012 & 0.67 & 0.85 & -0.18 & 0.67 & 0.89 & -0.23 \\
\hline 2013 & 0.66 & 0.82 & -0.16 & 0.66 & 0.80 & -0.14 \\
\hline 2014 & 0.69 & 0.81 & -0.12 & 0.69 & 0.78 & -0.09 \\
\hline 2015 & 0.72 & 0.79 & -0.07 & 0.72 & 0.77 & -0.05 \\
\hline
\end{tabular}

Notes: Actual percent is the number of dividend-paying firms divided by the total number of firms in the sample that year, Expected percent is the percentage of firms that would be expected to be dividend payers based on prevailing sample characteristics, PTP is the propensity to pay dividends which are defined as the difference between the actual and expected percentage of dividend-paying firms.

difference between the actual and the expected percentage of dividendpaying firms. This study considers that the propensity to pay dividends $\left(P T P_{t}\right)$ has increased in the year $t$ when the expected proportion of the dividend-paying firms is lower than the actual percentage of the dividend-paying firms. There were actually three distinct trends in the propensity to pay dividends $\left(P T P_{t}\right)$ between 1995 and 2015. First, the propensity to pay dividends had decreased from 1995 through 2002. 
Then, it increased from 2003 through 2008 thereafter and finally, it again decreased from 2009 through 2015.

\subsection{Proxies Capturing the Dividend Premium}

Following Baker and Wurgler (2004a), the current study used dividend premiums to measure the catering incentives of dividends, which captured the relative market valuation of the dividend-paying firms versus the non-dividend paying firms. Dividend premiums were computed in the following way: For every year $t$, the weighted average market-to-book ratio (the market-to-book ratio is equal to market value of equity divided by book value of equity) for the dividendpaying firms, and the non-dividend paying firms were calculated. The difference between the natural logarithms of these averages was defined as dividend premium $\left(D P^{P-N P t}\right)$. This study considered the equal and the weighted averages of the market to book ratio separately for the dividend-paying firms and the non-dividend paying firms. Thus, the dividend premiums $\left(D P^{P-N P t}\right)$ could be defined as the difference between the log of equally, or value weighted, average market-to-book ratio of the dividend-paying firms, and the non-dividend paying firms. This is represented as follows:

$$
\mathrm{DP}_{\mathrm{t}}^{\mathrm{P}-\mathrm{NP}}=\ln \left(\sum_{\mathrm{i}} \mathrm{w}_{\mathrm{ti}}^{\mathrm{p}} \frac{\mathrm{M}_{\mathrm{ti}}^{\mathrm{p}}}{\mathrm{B}_{\mathrm{ti}}^{\mathrm{p}}}\right)-\ln \left(\sum_{\mathrm{i}} \mathrm{w}_{\mathrm{ti}}^{\mathrm{np}} \frac{\mathrm{M}_{\mathrm{ti}}^{\mathrm{np}}}{\mathrm{B}_{\mathrm{ti}}^{\mathrm{np}}}\right)
$$

where:

$\mathrm{DP}_{\mathrm{t}}^{\mathrm{P}-\mathrm{NP}}=$ Dividend premium in a given year $t$,

$\mathrm{w}_{\mathrm{ti}}^{\mathrm{p}}:=$ Weight of firm $i$ in the subset of dividend paying firms in a given year $t$,

$\mathrm{M}_{\mathrm{ti}}^{\mathrm{p}}=$ Market value of equity of firm $i$ in the subset of dividend paying firms in year $t$,

$\mathrm{B}_{\mathrm{ti}}^{\mathrm{p}}=$ Book value of equity of firm $i$ in the subset of dividend paying firms in year $t$,

$\mathrm{w}_{\mathrm{ti}}^{\mathrm{np}}=$ Weight of firm $i$ in the subset of non-dividend paying firms in a given year $t$,

$\mathrm{M}_{\mathrm{ti}}^{\mathrm{np}}=$ Market value of equity of firm $i$ in the subset of non-dividend paying firms in year $t$, 


$$
\begin{aligned}
\mathrm{B}_{\mathrm{ti}}^{\mathrm{np}}= & \text { Book value of equity of firm } i \text { in the subset of non-dividend } \\
& \text { paying firms in year } t,
\end{aligned}
$$

Figure 1 and Figure 2 are provided to illustrate the outcomes further. Figure 1 plots the change in the propensity to pay dividends $\left(P T P_{t}\right)$ with the market-to-book ratio $(M B R)$ included, and the valueweighted dividend premiums during 1995-2015. Figure 2 plots the change in the propensity to pay dividends $\left(P T P_{t}\right)$ with the market-tobook ratio $(M B R)$ being excluded, and the value-weighted dividend premium during 1995-2015. In Figures 1 and 2, the dividend premiums predicted the decreasing propensity to pay dividends during 1995-2002. The dividend premiums appeared positive when predicting the rising propensity to pay dividends from 2003 through 2008, but thereafter, the dividend premiums turned negative when predicting the declining propensity to pay dividends during 2009-2015.

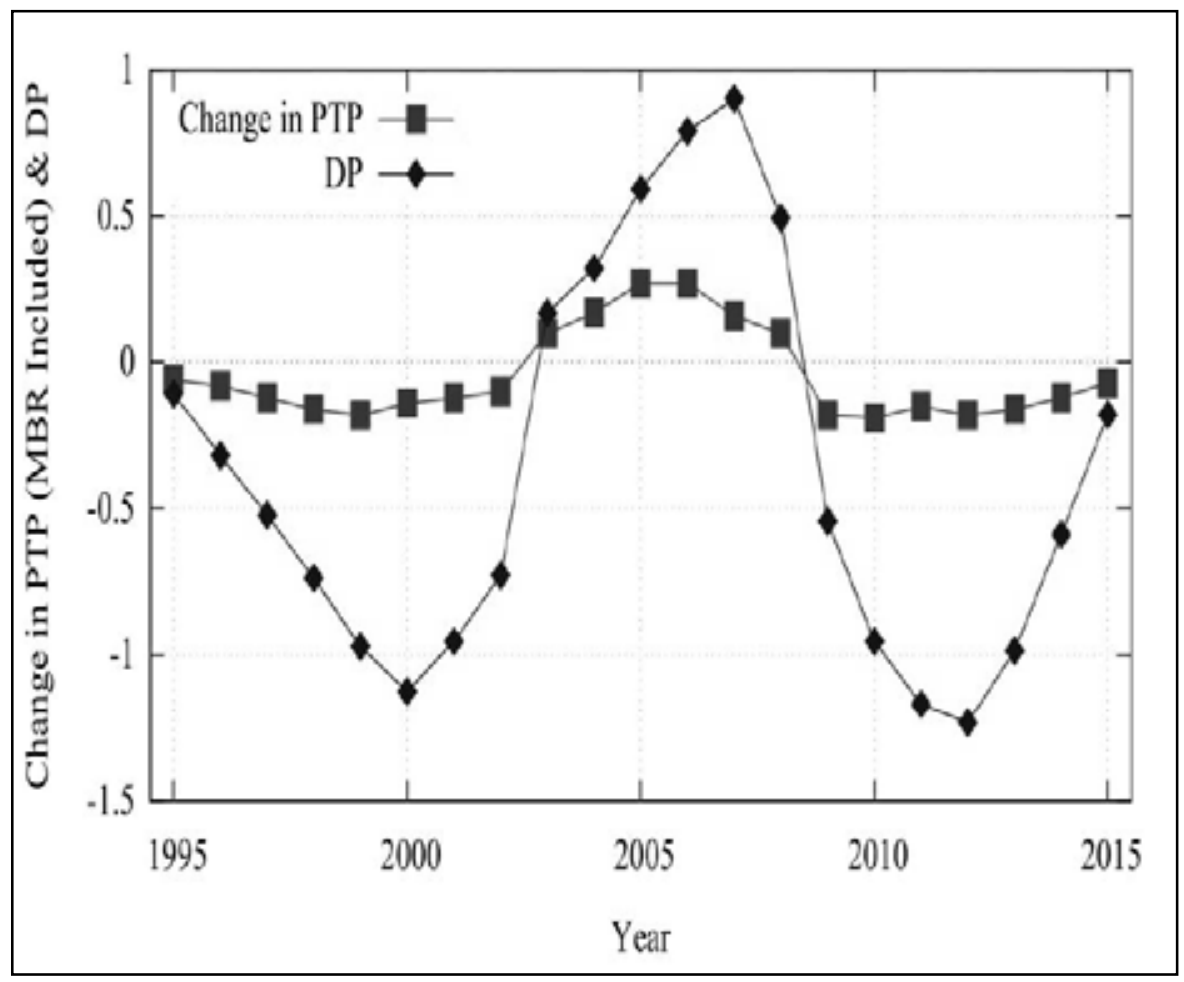

Figure 1: Change in Propensity to Pay Dividends (MBR Included) and Dividend Premium (Value Weighted) 


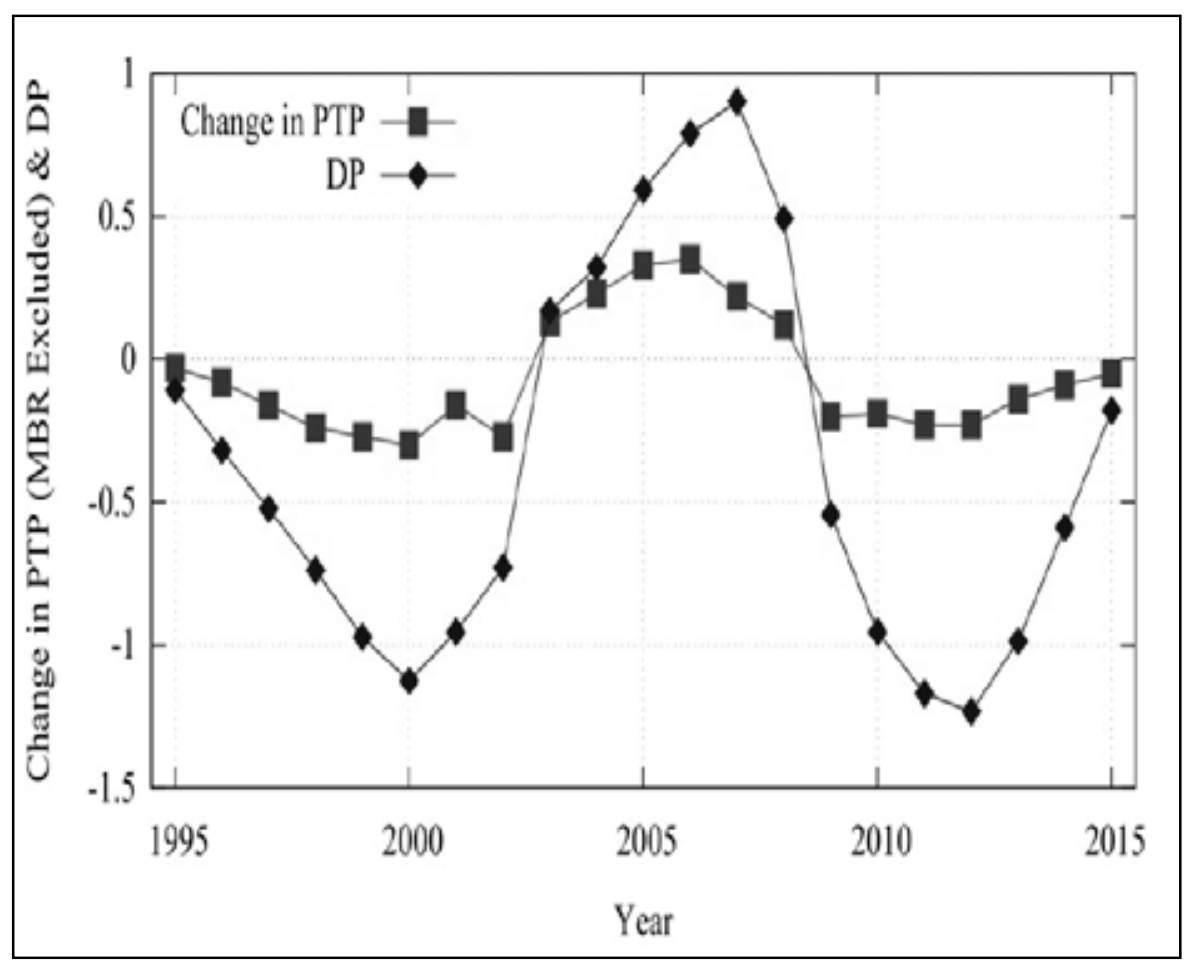

Figure 2: Change in Propensity to Pay Dividends (MBR Excluded) and Dividend Premium (Value Weighted)

\section{Model Specification and Methodology}

\subsection{Dividend Premiums and Propensity to Pay Dividends}

To empirically test the link between the catering incentives of dividends, and the propensity to pay dividends, the current study regressed the changes in propensity to pay $\left(\triangle P T P_{t}\right)$ variable against the lagged dividend premiums $\left(D P^{P-N P}{ }_{t-1}\right)$ variable. The regression model takes the following equation:

$$
\Delta \mathrm{PTP}_{\mathrm{t}}=\alpha+\beta \mathrm{DP}_{\mathrm{t}-1}^{\mathrm{P}-\mathrm{NP}}+\varepsilon_{\mathrm{t}}
$$

where $\triangle P T P_{t}$ indicates the changes in the propensity to pay dividends, $D P^{P-N P}{ }_{t-1}$ is the lagged dividend premiums representing the catering incentives of dividends, $\alpha$ is a constant, $\beta$ is a slope coefficient, and $\varepsilon_{t}$ is the error term in year $t$. 
Acharya, Gujral, Kulkarni and Shin (2011) mentioned that the global financial crisis had a significant positive impact on the dividend payment decisions of firms which supported the signalling hypothesis. Therefore, to examine the potential influence of the financial crisis - the Asian financial crisis (1997-1999), and the Global financial crisis (20072011), on the firms' decision to pay dividends, the study inculcated the financial crisis dummy variable $\left(F_{\text {crisis,t }}\right)$ in the regression model (4) such that the new model is specified as using the following equation.

$$
\Delta \mathrm{PTP}_{\mathrm{t}}=\alpha+\beta_{1} \mathrm{DP}_{\mathrm{t}-1}^{\mathrm{P}-\mathrm{NP}}+\beta_{2} \mathrm{~F}_{\text {crisis, }}+\varepsilon_{\mathrm{t}}
$$

where $\triangle P T P_{t}$ indicates the changes in the propensity to pay dividends, $D P^{P-N P}{ }_{t-1}, D P^{P-N P}{ }_{t-1}$ the lagged dividend premiums representing the catering incentives of dividends, $F_{\text {crisis,t }}$ is the financial crisis dummy variable which takes the value 1 in a given year when there is a financial crisis in that year and zero for otherwise; $\alpha$ is a constant, $\beta$ is a slope coefficient, and $\varepsilon_{t}$ is the error term in year $t$.

To examine the influence of the dividend premiums on the propensity to pay dividends with market-to-book ratio included and excluded, this study estimated equations (4) and (5) by utilising the ordinary least square (OLS) regression analysis. The values of the ordinary least square (OLS) coefficients are reported in Tables 5 and 6.

\subsection{Dividend Premiums and Change in Dividend Payment Decisions}

Baker and Wurgler (2004a) provided a discrete model which considered only two dividend payment decisions, i.e., the decision to initiate or to omit dividends. When the investors' demand for the dividend-paying stocks was high, i.e., the dividend-paying stocks were trading at the dividend premiums which were relative to the non-dividend paying stocks, the managers would rationally cater to the investors' demand for dividends while the non-dividend paying firms would likewise, initiate the dividends payment. Conversely, the dividend-paying firms would omit dividend payments when the stocks of the dividend-paying firms were trading at the dividend discount that is relative to the nondividend paying stocks. Thus, Baker and Wurgler's (2004a) discrete model considers whether to pay or not to pay the dividends, but it does not consider the dividend payout levels.

In order to examine the influence of the dividend premiums on firms' decision to change dividend payments, the current study estimated the multinomial logit model. Apart from the dividend 
premiums variable, this study also utilised other control variables which comprised factors that may affect the firms' dividend payment decisions. These control variables included the investment opportunities (INVT), financial leverage (LEV), business risks (BR), life cycle (LC), firm's size (SIZE), and profitability (PROF) as the determinants for the firms' dividend payment decisions. Following the different theories of dividend policy, such as signalling, pecking order, transaction cost, and firm life cycle, this study predicted that the firm's investment opportunities, financial leverage, and business risks would be negatively associated with the dividend payment decisions (Myers, 1984; Myers \& Majluf, 1984; Bhattacharya, 1979; Aharony \& Swary, 1980; Asquith \& Mullins, 1983). Further to this, the current study also predicted that the firm's life cycle stage, size and profitability would be positively associated with the dividend payment decisions (Grullon, Michaely, \& Swaminathan, 2002; DeAngelo et al., 2006; Bulan \& Subramanian, 2009; Denis \& Osobov, 2008; Higgins, 1972).The multinomial logit model was thus estimated based on the following equation:

$$
\begin{aligned}
\mathrm{Y}_{\mathrm{i}, \mathrm{t}}= & \operatorname{logit}\left(\alpha+\beta_{1} \mathrm{VW} \mathrm{DP}^{\mathrm{P}-\mathrm{NP}}+\beta_{\mathrm{t}-1} \mathrm{INVT}_{\mathrm{i}, \mathrm{t}}+\beta_{3} \mathrm{LEV}_{\mathrm{i}, \mathrm{t}}+\right. \\
& \left.\beta_{6} \mathrm{BR}_{\mathrm{i}, \mathrm{t}}+\beta_{7} \mathrm{LC}_{\mathrm{i}, \mathrm{t}}+\beta_{8} \mathrm{SIZE}_{\mathrm{i}, \mathrm{t}}+\beta_{9} \mathrm{PROF}_{\mathrm{i}, \mathrm{t}}+\varepsilon_{\mathrm{i}, \mathrm{t}}\right)
\end{aligned}
$$

where, $V W D P^{P-N P}{ }_{t-1}$ is value-weighted dividend premium; $I N V T_{i, t}$ is investment opportunity measured as market-to-book ratio for firm $i$ in period $t ; L E V_{i, t}$ is leverage ratio measured as debt-to-capital ratio for firm $i$ in period $t ; B R_{i, t}$ is standard deviation of the first difference of operating income divided by the total assets for firm $i$ in period $t ; L C_{i, t}$ is the life cycle variable measured as ratio between retained earnings to total equity for firm $i$ in period $t ; S I Z E_{i, t}$ is the size variable measured as the natural $\log$ of market capitalisation for firm $i$ in period $t$; $P R O F_{i, t}$ is the profitability variable measured as return on assets, i.e., earnings before interest, and taxes divided by total assets for firm $i$ in period $t ; \alpha$ is a constant; $\beta$ s are the slope coefficients; and $\varepsilon_{i, t}$ is the error term for firm $i$ in period $t$.

This study measured the dividends payout levels' decisions, that is, how much dividends to pay, by the changes in the dividends payment. The change in the dividends payment was calculated by subtracting the dividends paid in the previous year from the dividends paid in a current year. These changes in dividends payment were classified into three categories - dividend increase, dividend decrease, and no change in dividends payments. When the firms paid more dividends in the current year than from the previous year, the study referred to this decision as 
the 'dividend increase', and where the firms paid less dividends in the current year than what was paid in the previous year, the study referred to this decision as the 'dividend decrease'. When the firms paid the same amount of dividends in the previous as well as current year, the study referred to this decision as 'no change'. $Y_{i, t}$ in equation (6) takes the value of 1 when there is a dividend increase, a value of 2 when there is a dividend decrease, and a value of 3 when there was no change in dividends payments.

This study also divided the 'dividend decrease' decision into two parts - the 'dividend cut' decision, and the 'dividend omit' decision. When the firms reduced the amount of dividends in the current year as compared to previous year, but still paid the dividends, it is referred to as the 'dividend cut' decision. In contrast, when the firms paying a dividend in the previous year do not pay any dividend in the current year, this is referred to as the 'dividend omit' decision. $Y_{i, t}$ in equation (6) takes the value of 1 when there is a dividend increase, the value of 2 when there is a dividend cut, and a value of 3 when there is a dividend omit, and finally, a value of 4 when there is no change in dividends payment.

To investigate the relationship between the dividend premiums which measured the investors' demand for dividends, and the decision to change the dividends payment, this study estimated equation (6) by utilising the multinomial logit model which examined the impact of the dividend premiums on the decision to change dividend payments. The results are reported in Table 7.

This study also examined the relationship between the dividend premiums, and the absolute change in the dividend payments. The impact of the dividend premiums on the absolute dividend change was examined using the same set of control variables. The absolute change in the dividend payments decision was divided into two types 'dividend increase' and 'dividend decrease'. The model takes the following equation:

$$
\begin{aligned}
\Delta \mathrm{DIV}_{\mathrm{i}, \mathrm{t}}= & \alpha+\beta_{1} \mathrm{VW} \mathrm{DP}^{\mathrm{P}-\mathrm{NP}} \mathrm{t}_{\mathrm{t}-\mathrm{1}}+\beta_{2} \mathrm{INVT}_{\mathrm{i}, \mathrm{t}}+\beta_{3} \mathrm{LEV}_{\mathrm{i}, \mathrm{t}}+\beta_{6} \mathrm{BR}_{\mathrm{i}, \mathrm{t}}+ \\
& \beta_{7} \mathrm{LC}_{\mathrm{i}, \mathrm{t}}+\beta_{8} \mathrm{SIZE}_{\mathrm{i}, \mathrm{t}}+\beta_{9} \mathrm{PROF}_{\mathrm{i}, \mathrm{t}}+\varepsilon_{\mathrm{i}, \mathrm{t}}
\end{aligned}
$$

where, $\Delta D I V_{i, t}$ is the absolute change in the dividend payments, and it takes the actual value of change in the dividend payout ratio of firms from the last year to the current year: $V W D P^{P-N P}{ }_{t-1}, I N V T_{i, t}, B R_{i, t}, L C_{i, t}$ $S I Z E_{i, t}$ and $P R O F_{i, t}$ as explained in equation (6). 
This study also examined the relationship between the dividend premiums, and the absolute change in dividend level with the same set of control variables by estimating equation (7). For this, the ordinary least square (OLS) regression analysis was used. The coefficients of the ordinary least square (OLS) are reported in Table 8.

\section{Results and Discussion}

\subsection{Summary Statistics and Correlation Matrix}

The summary statistics, the correlation matrix, and the variance inflating factor results of all the independent variables used in the regression analysis are presented in Tables 3 and 4 . The skewness and kurtosis values of all the variables are observed to be in the acceptable range, that is, skewness is between \pm 3 , and kurtosis is between \pm 10 . This implies that the data are normalised (Kline, 2005). Although the correlation coefficients between some of the independent variables are significant, the values of the correlation coefficients, and the VIF indicate an absence of the multicollinearity problems.

Table 3: Descriptive Statistics

\begin{tabular}{lrrrcccc}
\hline Variable & Min & Max & Mean & Median & Std. Dev. & Skewness & Kurtosis \\
\hline INVT & -2.90 & 18.88 & 2.12 & 1.18 & 2.73 & 2.58 & 8.11 \\
LEV & 0.00 & 6.79 & 1.09 & 0.87 & 1.07 & 1.80 & 4.37 \\
BR & 0.01 & 0.18 & 0.04 & 0.03 & 0.03 & 2.38 & 7.26 \\
LC & -0.30 & 0.25 & 0.03 & 0.03 & 0.06 & -0.96 & 4.90 \\
SIZE & -1.90 & 12.95 & 4.78 & 4.62 & 2.12 & 0.37 & 0.13 \\
PROF & -0.57 & 1.27 & 0.15 & 0.14 & 0.19 & 1.21 & 7.09 \\
\hline
\end{tabular}

Notes: This table presents summary statistics for all the independent variables used in the regression analysis during 1995-2015. INVT is a firm's investment opportunity measured as market value of equity divided by book value of equity, LEV is a firm's financial leverage defined as total debt divided by total capital employed, BR is a firm's business risk defined as the standard deviation of the first difference of operating income divided by total assets, LC is a life cycle variable for a firm defined as the ratio of retained earnings to total equity, SIZE is firm's size measured as the natural log of market capitalisation, PROF is a firm's return on assets measured as earnings before interest and taxes divided by total assets. 
Table 4: Correlation Matrix and Variance Inflation Factor (VIF)

\begin{tabular}{lccclll}
\hline Variables & INVT & LEV & BR & LC & SIZE & PROF \\
\hline INVT & 1.000 & & & & & \\
LEV & $-0.04^{* * *}$ & 1.00 & & & & \\
BR & $-0.02^{* * *}$ & $-0.10^{* * *}$ & 1.00 & & & \\
LC & $0.23^{* * *}$ & $-0.25^{* * *}$ & $-0.13^{* * *}$ & 1.00 & & \\
SIZE & $0.51^{* * *}$ & $-0.14^{* * *}$ & $-0.17^{* * *}$ & $0.30^{* * *}$ & 1.00 & \\
PROF & $0.23^{* * *}$ & $-0.16^{* * *}$ & 0.02 & $0.38^{* * *}$ & $0.24^{* * *}$ & 1.00 \\
VIF & 1.41 & 1.14 & 1.08 & 1.38 & 1.51 & 1.22 \\
\hline
\end{tabular}

Notes: This table reports the correlation matrix and variance inflation factor for all the independent variables used in the regression analysis during 1995-2015. For variable explanation see notes in Table $3 .{ }^{* * *}$ indicates significance at 1 per cent level, ${ }^{* *}$ indicates significance at 5 per cent level and * indicates significance at 10 per cent level.

\subsection{Catering Incentives and the Propensity to Pay Dividends}

In this study, the presence of a link between the catering incentives of dividends and the propensity to pay dividends was empirically tested by regressing the changes in the propensity to pay $\left(\triangle P T P_{t}\right)$ variable against the lagged dividend premium $\left(D P_{t-1}^{P-N P}\right)$ variable.

Table 5 reports the results of the regression analysis which was estimated based on equation (4) for period 1995-2015. In Table 5, the adjusted- $\mathrm{R}^{2}$ values for models (1) and (2) are 10.30 per cent, and 6.80 per cent, respectively while the F-statistics for both models (1) and (2) are noted to be statistically significant, at the 10 per cent level. The coefficient on the lagged dividend premium, $\left(D P_{t-1}^{P-N P}\right)$ is noted to be positive, and statistically significant for both models (1) and (2). This indicates that there is a direct relationship between the lagged dividend premiums with the change in propensity to pay dividends. Thus, when the dividend premiums are positive, that is, investors place premiums on the dividend payers, firm managers cater to the investors' demand for dividends by paying dividends. In contrast, firm managers do not pay the investors any dividends when the dividend premiums are negative. This outcome is consistent with the findings of Baker and Wurgler (2004a, 2004b), thereby supporting the catering incentives of the dividend payments. 
Table 5: Result of the Regression Analysis

\begin{tabular}{lcc}
\hline \multicolumn{2}{l}{ Change in Propensity to Pay Dividends as the Dependent Variable } \\
\hline Variable & $\begin{array}{c}\text { Model 1 } \\
\text { (MBR included) }\end{array}$ & $\begin{array}{c}\text { Model 2 } \\
\text { (MBR excluded) }\end{array}$ \\
\hline Constant & 0.02 & 0.03 \\
& $(0.81)$ & $(0.78)$ \\
$D P_{t-1}^{P-N P}$ & 0.05 & 0.07 \\
No. of Observations & $(1.86)^{*}$ & $(2.03)^{* *}$ \\
Adjusted-R & 21 & 21 \\
F-statistics & 0.103 & 0.068 \\
& $\mathrm{~F}(1,18)=3.46$ & $\mathrm{~F}(1,18)=4.13$ \\
Durbin-Watson & $(0.08)^{*}$ & $(0.06)^{*}$ \\
\end{tabular}

Notes: The figures in parentheses are the t-statistics. $D P_{t-1}^{P-N P}$ is the lagged value of dividend premium, ${ }^{* * *}$ indicates significance at 1 per cent level, ** indicates significance at 5 per cent level and * indicates significance at 10 per cent level.

Table 6 presents the results of the regression analysis with the financial crisis dummy variable included. This was estimated based on equation (5) for period 1995-2015. In Table 6, the possible effect of the financial crisis was controlled by introducing a financial crisis dummy variable. This was used to indicate the Asian financial crisis during 1997-1999, and the global financial crisis during 2007-2011. The financial crisis dummy variable takes the value of 1 in a given year when there is a financial crisis in that year, and zero for otherwise. The results in Table 6 indicate that the financial crisis dummy variable $F_{\text {crisis,t }}$ showed a negative sign for both models (1) and (2). This hints the negative effect of the financial crisis on the propensity to pay dividends. However, the coefficient on the financial crisis variable is not statistically significant at the conventional level. Therefore, the financial crisis has very little, or no impact on the propensity to pay dividends. The coefficient on the lagged dividend premiums is observed to be positive, and statistically significant at the five percent level, for both models (1) and (2). These findings confirm the presence of the catering incentives of dividends payment in India. In Table 6 , the adjusted- $R^{2}$ values for models (1) and (2) are 34.60 per cent and 26.80 per cent, respectively while the 
Table 6: Result of the Regression Analysis with Financial Crisis Dummy Variable Included

Change in Propensity to Pay Dividends as the Dependent Variable

\begin{tabular}{lcc}
\hline Variable & $\begin{array}{c}\text { Model 1 } \\
\text { (MBR included) }\end{array}$ & $\begin{array}{c}\text { Model 2 } \\
\text { (MBR excluded) }\end{array}$ \\
\hline Constant & 0.03 & 0.04 \\
& $(1.11)$ & $(0.90)$ \\
$D P_{t-1}^{P-N P}$ & 0.12 & 0.16 \\
$\mathrm{~F}_{\text {crisis,t }}$ & $(2.94)^{* * *}$ & $(2.32)^{* *}$ \\
No. of Observations & -0.02 & -0.02 \\
Adjusted-R & $(-0.89)$ & $(-0.48)$ \\
F-statistics & 21 & 21 \\
& 0.346 & 0.268 \\
Durbin-Watson & $\mathrm{F}(2,17)=6.17$ & $\mathrm{~F}(2,17)=4.11$ \\
\hline
\end{tabular}

Notes: The figures in parentheses are the t-statistics. $D P_{t-1}^{P-N P}$ is the lagged value of dividend premium $F_{\text {crisis,t }}$ is the financial crisis dummy variable. ${ }^{* * *}$ indicates significance at 1 per cent level, ${ }^{* *}$ indicates significance at 5 per cent level and * indicates significance at 10 per cent level.

F-statistics for both models (1) and (2) are noted to be statistically significant at the five per cent level of significance.

Baker and Wurgler (2004a) had offered a model which explained how the time-varying investors' demand for dividends can influence firms' decision to initiate and omit the dividends. But more often in practice, firm managers are confronted with the decision to change the dividend levels that is, to increase or decrease the dividends rather than the decision to initiate or omit dividends. Based on this, it is important to interrogate the impact of the catering incentives on the decision to change the dividend levels. Table 7 presents the result of the multinomial logit model, based on equation (6), which highlight the influence of the catering incentives on the decision to change dividend levels. The dividend premiums capturing the investors' demand for dividends are deduced to be positively related to the decision so as to increase the dividend levels. However, they are expected to be negatively associated with the decision so as to decrease the dividend 
levels. Firm managers tend to cater to the investors' demand for dividends by increasing the dividend levels when investors show a higher demand for dividends. This shows that investors' higher demand for dividends would discourage the firm managers from cutting or omitting the dividends.

The results in Table 7 also indicate that the value-weighted dividend premiums are significantly and positively associated with the decision to increase the dividend levels. However, they are significantly and negatively related to the decision to decrease the dividend levels. This result can be interpreted as saying that the higher dividend premiums reflecting the investors' higher demand for dividends can induce the firm managers to increase the amount of dividends paid. At the same time, the investors' higher demand for dividends would discourage the firm managers from decreasing the amount of dividend levels. This result support the catering theory of dividends since the firm managers are more likely to increase the dividend levels when there is a higher demand for dividends by investors as indicated by the higher dividend premiums.

This study had classified the firms' decision to decrease the dividend levels as the decision to cut the dividend levels. This is divided into two sub-categories: dividend cut and dividend omit. Model 2 in Table 7 shows the multinomial logit regression analysis for the dividend levels change decisions, such as dividend increase, dividend cut and dividend omit. The results for Model 2 are noted to be similar to those obtained for Model 1. The value-weighted dividend premiums also carry a significant positive association with the dividend increasing decision. In contrast, it has a significant and negative relationship with the dividend cutting, and dividend omitting decisions. The result thereby suggests that the negative association of the dividend premium with the dividend decreasing decision, is more pronounced for the decision to omit dividends than the decision to cut the dividends. This result also supports the catering theory of dividends since the firm managers are less likely to cut or omit the dividends when the investors' demand for dividends are high when the dividend premiums were also high.

Table 8 presents the results for the estimation of a regression model based on equation (7). It reports the impact of the value-weighted dividend premium, and other proxy variables, on the absolute change in the dividend levels. The result obtained in Table 8 differ significantly from those obtained for the multinomial logit regression analysis shown in Table 7. The value-weighted dividend premiums show a significant 
Table 7: Result of the Multinomial Logit Regression Analysis for Dividend Changes

\begin{tabular}{|c|c|c|c|c|c|}
\hline \multirow[b]{2}{*}{ Variables } & \multicolumn{2}{|c|}{ Model 1} & \multicolumn{3}{|c|}{ Model 2} \\
\hline & $\begin{array}{l}\text { Dividend } \\
\text { increasing }\end{array}$ & $\begin{array}{c}\text { Dividend } \\
\text { decreasing }\end{array}$ & $\begin{array}{l}\text { Dividend } \\
\text { increasing }\end{array}$ & $\begin{array}{l}\text { Dividend } \\
\text { cutting }\end{array}$ & $\begin{array}{c}\text { Dividend } \\
\text { omitting }\end{array}$ \\
\hline Constant & $\begin{array}{c}-1.26 \\
(-16.28)^{\star * *}\end{array}$ & $\begin{array}{c}-1.30 \\
(-14.97)^{* * *}\end{array}$ & $\begin{array}{c}-1.31 \\
(-16.79)^{* * *}\end{array}$ & $\begin{array}{c}-1.94 \\
(-19.16)^{* * *}\end{array}$ & $\begin{array}{c}-1.85 \\
(-13.30)^{* * *}\end{array}$ \\
\hline $\mathrm{VW} D P_{t-1}^{P-N P}$ & $\begin{array}{c}0.10 \\
(3.38) * * *\end{array}$ & $\begin{array}{l}-0.27 \\
(-7.28)^{\star * *}\end{array}$ & $\begin{array}{l}0.10 \\
(3.46)^{* * *}\end{array}$ & $\begin{array}{l}-0.22 \\
(-5.18)^{* * *}\end{array}$ & $\begin{array}{l}-0.39 \\
(-5.71)^{* * *}\end{array}$ \\
\hline INVT & $\begin{array}{c}-0.01 \\
(-0.80)\end{array}$ & $\begin{array}{l}-0.08 \\
(-6.15)^{\star * *}\end{array}$ & $\begin{array}{c}-0.01 \\
(-1.22)\end{array}$ & $\begin{array}{l}-0.11 \\
(-7.14)^{\star * *}\end{array}$ & $\begin{array}{l}-0.06 \\
(-2.41)^{* *}\end{array}$ \\
\hline LEV & $\begin{array}{l}-0.09 \\
(-4.08) * * *\end{array}$ & $\begin{array}{c}-0.01 \\
(-0.35)\end{array}$ & $\begin{array}{l}-0.09 \\
(-4.41)^{* * *}\end{array}$ & $\begin{array}{l}-0.09 \\
(-3.06)^{* * *}\end{array}$ & $\begin{array}{l}0.12 \\
(3.76)^{* * *}\end{array}$ \\
\hline $\mathrm{BR}$ & $\begin{array}{l}-15.89 \\
(-17.14) * * *\end{array}$ & $\begin{array}{l}-8.35 \\
(-8.24)^{\star * *}\end{array}$ & $\begin{array}{l}-16.13 \\
(-17.29)^{* * *}\end{array}$ & $\begin{array}{l}-9.81 \\
(-8.13)^{\star * *}\end{array}$ & $\begin{array}{l}-8.27 \\
(-4.87)^{\star * *}\end{array}$ \\
\hline $\mathrm{LC}$ & $\begin{array}{l}12.05 \\
(23.95) * * *\end{array}$ & $\begin{array}{l}1.71 \\
(3.49)^{\star * *}\end{array}$ & $\begin{array}{l}12.50 \\
(24.37)^{\star * *}\end{array}$ & $\begin{array}{l}4.34 \\
(7.18)^{\star * *}\end{array}$ & $\begin{array}{l}-2.85 \\
(-3.94)^{\star * *}\end{array}$ \\
\hline SIZE & $\begin{array}{c}0.28 \\
(22.99) * * *\end{array}$ & $\begin{array}{c}0.21 \\
(14.36)^{* * *}\end{array}$ & $\begin{array}{c}0.29 \\
(23.50)^{* * *}\end{array}$ & $\begin{array}{c}0.28 \\
(17.29)^{* * *}\end{array}$ & $\begin{array}{c}-0.01 \\
(-0.15)\end{array}$ \\
\hline PROF & $\begin{array}{l}1.07 \\
(8.27)^{* * *}\end{array}$ & $\begin{array}{l}-1.32 \\
(-8.35)^{\star * *}\end{array}$ & $\begin{array}{l}1.18 \\
(8.86)^{* * *}\end{array}$ & $\begin{array}{l}-0.36 \\
(-1.97)^{\star *}\end{array}$ & $\begin{array}{c}-3.08 \\
(-12.82)^{* * *}\end{array}$ \\
\hline $\begin{array}{l}\text { No. of } \\
\text { Observation }\end{array}$ & \multicolumn{2}{|c|}{16401} & \multicolumn{3}{|c|}{16401} \\
\hline Pseudo $\mathrm{R}^{2}$ & \multicolumn{2}{|c|}{0.129} & \multicolumn{3}{|c|}{0.135} \\
\hline $\begin{array}{l}\text { Log } \\
\text { Likelihood }\end{array}$ & \multicolumn{2}{|c|}{-13390.71} & \multicolumn{3}{|c|}{-14661.04} \\
\hline LR Test & \multicolumn{2}{|c|}{$\begin{array}{c}X^{2}(14)=3973.42 \\
(0.00)\end{array}$} & \multicolumn{3}{|c|}{$\begin{array}{c}X^{2}(21)=4564.13 \\
(0.00)\end{array}$} \\
\hline
\end{tabular}

Notes: VW $D P_{t-1}^{P-N P}$ is value weighted dividend premium which is defined as the difference between the log-normally distributed value weighted average market-to-book ratio of dividend paying firms and non-dividend paying firms. INVT, LEV, BR, LC, SIZE and PROF are as explained in Table 3. The figures in parentheses are the z-statistics. ${ }^{* * *}$ indicates significance at 1 per cent level, ${ }^{* *}$ indicates significance at 5 per cent level and * indicates significance at 10 per cent level. 
Table 8: Result of the Regression Analysis for Absolute Change in Dividend Levels

\begin{tabular}{|c|c|c|c|c|}
\hline \multirow[b]{2}{*}{ Variables } & \multicolumn{2}{|c|}{ Dividend Increasing } & \multicolumn{2}{|c|}{ Dividend Decreasing } \\
\hline & Only DP & Full model & Only DP & Full model \\
\hline Constant & $\begin{array}{c}1.66 \\
(61.62)^{\star * *}\end{array}$ & $\begin{array}{l}-0.23 \\
(-2.30)^{* *}\end{array}$ & $\begin{array}{c}-1.04 \\
(-38.18)^{\star * *}\end{array}$ & $\begin{array}{l}-0.16 \\
(-2.12)^{\star *}\end{array}$ \\
\hline $\mathrm{VW} D P_{t-1}^{P-N P}$ & $\begin{array}{l}0.13 \\
(3.66)^{* * *}\end{array}$ & $\begin{array}{l}0.09 \\
(2.73)^{\star * *}\end{array}$ & $\begin{array}{c}0.03 \\
(0.73)\end{array}$ & $\begin{array}{c}0.02 \\
(0.60)\end{array}$ \\
\hline INVT & & $\begin{array}{l}-0.05 \\
(-4.82)^{\star * *}\end{array}$ & & $\begin{array}{l}0.10 \\
(8.40)^{* * *}\end{array}$ \\
\hline LEV & & $\begin{array}{c}0.04 \\
(1.21)\end{array}$ & & $\begin{array}{l}-0.08 \\
(-4.01)^{\star * *}\end{array}$ \\
\hline BR & & $\begin{array}{c}0.01 \\
(0.00)\end{array}$ & & $\begin{array}{l}-3.05 \\
(-3.47)^{* * *}\end{array}$ \\
\hline $\mathrm{LC}$ & & $\begin{array}{l}3.16 \\
(5.34)^{* * *}\end{array}$ & & $\begin{array}{l}1.12 \\
(2.03)^{* *}\end{array}$ \\
\hline SIZE & & $\begin{array}{c}0.32 \\
(23.34)^{\star * *}\end{array}$ & & $\begin{array}{c}-0.21 \\
(-15.18)^{\star * *}\end{array}$ \\
\hline PROF & & $\begin{array}{c}0.04 \\
(0.26)\end{array}$ & & $\begin{array}{c}0.02 \\
(0.15)\end{array}$ \\
\hline $\begin{array}{l}\text { No. of } \\
\text { Observations }\end{array}$ & 6913 & 6913 & 1877 & 1877 \\
\hline Adjusted-R ${ }^{2}$ & 0.081 & 0.144 & 0.078 & 0.121 \\
\hline F-statistics & $\begin{array}{c}F(1,6911)= \\
13.40 \\
(0.00)\end{array}$ & $\begin{array}{c}F(7,6905)= \\
101.43 \\
(0.00)\end{array}$ & $\begin{array}{c}F(1,1875)= \\
10.53 \\
(0.00)\end{array}$ & $\begin{array}{c}F(7,1869)= \\
35.97 \\
(0.00)\end{array}$ \\
\hline
\end{tabular}

Notes: VW $D P_{t-1}^{P-N P}$ is as explained in Table 7. INVT, LEV, BR, LC, SIZE and PROF are as explained in Table 3. The figures in parentheses are the t-statistics. ${ }^{* * *}$ indicates significance at 1 per cent level, ${ }^{* *}$ indicates significance at 5 per cent level and * indicates significance at 10 per cent level.

and positive relationship with the decision to increase the dividends level. In contrast, the association between the dividends premium, and the decision to decrease the dividends level is insignificant.

This result indicates that when the dividend premiums are high, it would also suggest a higher investors' demand for dividends, and for firm managers to cater to the investors' demand for dividends. This 
is accomplished by increasing the amount of dividend payments to the investors. Therefore, firm managers are more likely to increase the dividends level when there is a higher demand for dividends from the investors. On the other hand, the higher dividend premiums do not have any role, or the least role to play in the firms' decision to decrease the dividends level.

\section{Conclusion}

This paper examines whether the catering incentives of dividends can influence firms' dividends payment decisions. A total of 781 sample firms listed on the National Stock Exchange (NSE) in India during 199495 to 2014-15 were employed. The dividend premiums, as a proxy to measure the time-varying investors' desire for dividends, were captured in each year during the study period. The dividend premiums were mostly negative for most of the years of the study. This is consistent with the previous research studies in the USA which found three distinct trends in the propensity to pay dividends between 1995 and 2015. The propensity to pay dividends had also decreased from 1995 through to 2002, and it then increased from 2003 to until 2008. Thereafter, it decreased again from 2009 to 2015. These trends in the propensity to pay dividends are found to be related to the corresponding variations in the dividend premiums which reflect the investors' demand for dividends. The empirical results of this study also show that there is a link existing between the catering incentives, and the propensity to pay dividends. This is deduced as that the catering incentives have a significant positive impact on the changes in the propensity to pay dividends. Therefore, when dividend premiums are positive, that is, investors place a premium on dividend payers, managers cater to the investors demand for dividends by paying dividends. Likewise, when the dividend premiums are negative, no dividends are paid to the investors.

The empirical result showing the influence of the dividend premiums on the probability to change dividend levels implies that the dividend premiums are significantly and positively associated with the probability of an increase in the dividend level, but it is negatively related to the probability of a decrease in the dividend level. The negative association of the dividend premiums with the dividend decreasing decision is more pronounced for the decision to omit dividends than the decision to cut the dividends. These findings indicate that the higher dividend premiums show a higher investors' demand for 
dividends. This can induce the firm managers to increase the amount of dividends paid. Contrary to that, the firm managers are less likely to cut or omit dividends when the investors' demand for dividends are high as reflected by the higher dividend premiums. In the case of the results for the impact of catering incentives of dividends on the absolute change in dividend levels, the dividend premium shows a significant and positive relationship with the absolute increase in the dividends level. However, the association between the dividend premiums, and the absolute decrease in dividend levels is insignificant.

Overall, the results generated support the notion that managers of Indian firms cater rationally to the investors demand for dividends, by paying dividends when investors place a premium on dividendpaying firms, and vice-versa. This study bears one implication for the management. The investors in the Indian capital market show a preference for dividend payments. In this regard, the firm managers could use these catering incentives as a factor for deciding the dividend payments to investors. Based on this, the firm managers should also consider other market-specific variables like the dividend premiums while formulating the appropriate dividend policy for the firm, apart from firm-specific variables.

\section{References}

Acharya, V.V., Gujral, I., Kulkarni, N., \& Shin, H.S. (2011). Dividends and bank capital in the financial crisis of 2007-2009 (NBER working paper No. 16896). Cambridge, MA: National Bureau of Economic Research. Retrieved from http://www.nber.org/papers/w16896

Aharony, J., \& Swary, I. (1980). Quarterly dividend and earnings announcements and stockholders' returns: An empirical analysis. The Journal of Finance, 35(1), 1-12. http://dx.doi.org/10.1111/j.1540-6261.1980.tb03466.x

Asquith, P., \& Mullins, D.W. (1983). The impact of initiating dividend payments on shareholders' wealth. Journal of Business, 56(1), 77-96.

Baker, H.K., \& Kapoor, S. (2015). Dividend policy in India: New survey evidence. Managerial Finance, 41(2), 182-204. http://dx.doi.org/10.1108/ MF-01-2014-0024

Baker, H.K., Kilincarslan, E., \& Arsal, A.H. (2018). Dividend policy in Turkey: Survey evidence from Borsa Istanbul firms. Global Finance Journal, 35(1), 4357. http:// dx.doi.org/10.1016/j.gfj.2017.04.002

Baker, M., \& Wurgler, J. (2004a). A catering theory of dividends. The Journal of Finance, 59(3), 1125-1165. http//dx.doi.org/10.1111/j.1540-6261.2004. 00658.x 
Baker, M., \& Wurgler, J. (2004b). Appearing and disappearing dividends: The link to catering incentives. Journal of Financial Economics, 73(2), 271-288. http://dx.doi.org/10.1016/j.jfineco.2003.08.001

Bhat, R., \& Pandey, I.M. (1994). Dividend decision: A study of managers' perceptions. Decision, 21(1\&2), 67-86.

Bhattacharya, S. (1979). Imperfect information, dividend policy, and "the bird in the hand" fallacy. The Bell Journal of Economics, 10(1), 259-270.

Black, F. (1976). The dividend puzzle. The Journal of Portfolio Management, 2(2), 5-8. http://dx.doi.org/10.3905/jpm.1976.408558

Budiarso, N.S., Subroto, B., Sutrisno, T., \& Pontoh, W. (2019). Dividend catering, life-cycle, and policy: Evidence from Indonesia. Cogent Economics \& Finance, 7(1), 1-15.

Bulan, L.T., \& Subramanian, N. (2009). The firm life cycle theory of dividends. In H.K. Baker (Ed.). Dividends and dividend policy (pp. 201-213). Hoboken, NJ: John Wiley \& Sons.

DeAngelo, H., DeAngelo, L., \& Stulz, R.M. (2006). Dividend policy and the earned/contributed capital mix: A test of the life-cycle theory. Journal of Financial Economics, 81(2), 227-254. http://dx.doi.org/10.1016/j.jfineco. 2005.07.005

Denis, D.J., \& Osobov, I. (2008). Why do firms pay dividends? International evidence on the determinants of dividend policy. Journal of Financial Economics, 89(1), 62-82. http://dx.doi.org/10.1016/j.jfineco.2007.06.006

Easterbrook, F.H. (1984). Two agency-cost explanations of dividends. The American Economic Review, 74(4), 650-659.

Fama, E.F., \& French, K.R. (2001). Disappearing dividends: Changing firm characteristics or lower propensity to pay? Journal of Financial Economics, 60(1), 3-43. http://dx.doi.org/10.1016/S0304-405X(01)00038-1

Ferris, S.P., Jayaraman, N., \& Sabherwal, S. (2009). Catering effects in corporate dividend policy: The international evidence. Journal of Banking $\mathcal{E}$ Finance, 33(9), 1730-1738. http://dx.doi.org/10.1016/j.jbankfin.2009.04.005

Ferris, S.P., Sen, N., \& Yui, H.P. (2006a). Are fewer firms paying more dividends?: The international evidence. Journal of Multinational Financial Management, 16(4), 333-362. http:/ / dx.doi.org/10.1016/j.mulfin.2005.08.002

Ferris, S.P., Sen, N., \& Yui, H.P. (2006b). God save the queen and her dividends: Corporate payouts in the United Kingdom. The Journal of Business, 79(3), 1149-1173. http://dx.doi.org/10.1086/500672

Grullon, G., Michaely, R., \& Swaminathan, B. (2002). Are dividend changes a sign of firm maturity? The Journal of Business, 75(3), 387-424. http/dx.doi. org/10.1086/339889

Higgins, R.C. (1972). The corporate dividend-saving decision. Journal of Financial and Quantitative Analysis, 7(2), 1527-1541. http://dx.doi.org/10.2307/ 2329932

Hoberg, G., \& Prabhala, N.R. (2008). Disappearing dividends, catering, and risk. The Review of Financial Studies, 22(1), 79-116. http://dx.doi.org/10.1093/ rfs/hhn073 
Jensen, M.C., \& Meckling, W.H. (1976). Theory of the firm: Managerial behavior, agency costs and ownership structure. Journal of Financial Economics, 3(4), 305-360. http:/ / dx.doi.org/10.1016/0304-405X(76)90026-X

Kline, R.B. (2005). Principles and practice of structural equation modeling (1st ed.). New York, NY: The Guilford Press.

Labhane, N.B. (2017). Disappearing and reappearing dividends in emerging markets: Evidence from Indian companies. Journal of Asia-Pacific Business, 18(1), 46-80. http:/ / dx.doi.org/10.1080/10599231.2017.1272996

Labhane, N.B., \& Mahakud, J. (2016). Determinants of dividend policy of Indian companies: A panel data analysis. Paradigm, 20(1), 36-55. http://dx.doi. org/ 10.1177/0971890716637698

Lintner, J. (1956). Distribution of incomes of corporations among dividends, retained earnings, and taxes. The American Economic Review, 46(2), 97-113.

Litzenberger, R.H., \& Ramaswamy, K. (1979). The effect of personal taxes and dividends on capital asset prices: Theory and empirical evidence. Journal of Financial Economics, 7(2), 163-195. http://dx.doi.org/10.1016/0304-405X (79)90012-6

Mahapatra, R.P., \& Sahu, P.K. (1993). A note on determinants of corporate dividend behaviour in India-an econometric analysis. Decision, 20(1), 1-22.

Miller, M.H., \& Modigliani, F. (1961). Dividend policy, growth, and the valuation of shares. The Journal of Business, 34(4), 411-433.

Myers, S.C. (1984). The capital structure puzzle. The Journal of Finance, 39(3), 574592. http:// dx.doi.org/10.1111/j.1540-6261.1984.tb03646.x

Myers, S.C., \& Majluf, N.S. (1984). Corporate financing and investment decisions when firms have information that investors do not have. Journal of Financial Economics, 13(2), 187-221. http:/ / dx.doi.org/10.1016/0304-405X(84)90023-0

Neves, M.E.D. (2017). Payout and firm's catering. International Journal of Economics and Business Administration, 5(4), 104-132.

Rozeff, M.S. (1982). Growth, beta and agency costs as determinants of dividend payout ratios. Journal of Financial Research, 5(3), 249-259. http://dx.doi.org/ 10.1111/j.1475-6803.1982.tb00299.x

Tangiitprom, N. (2013). Propensity to pay dividends and catering incentives in Thailand. Studies in Economics and Finance, 30(1), 45-55. http://dx.doi. org/10.1108/10867371311300973 